\title{
Palmoplantar pustulosis: Oral bacteria as a causative factor and ozone as an effective therapeutic means?
}

\section{Yasuhiro Horiuchi}

Division of Dermatology, Tsuruse Orthopedic Clinic, Saitama, Japan

Corresponding author: Dr. Yasuhiro Horiuchi, E-mail: tshoriuchi15@gmail.com

Sir,

In recent years, reports on bacteria that cause palmoplantar pustulosis (PPP) [1] have been accumulating $[2,3]$. Reliable means of treating PPP have yet to be adequately established. Although the complete removal of dental plaques and calculus by mechanical debridement may be difficult on occasions, periodontal therapy [3] for PPP patients has been reported to improve the skin lesions remarkably, suggesting the involvement of bacteria in PPP.

A male PPP patient aged 49 was presented to the clinic. He exhibited scaly erythemas, including several vesiculopustules on both soles and/or palms, but without extra-palmoplantar lesions and systemic symptoms such as joint pain, occurring in the past 2 years. Additionally, he had dental caries and gingivitis and was maintained on topical vitamin D analogues and steroid ointments for over 6 months. However, these treatments were minimally effective. At the exacerbated stage of his disease, antibiotics (Roxithromycin) were also administered for 5 months and skin lesions were alleviated, but did not heal completely. As he had previously worked for a company dealing with ozone gas-generating equipment and due to the antimicrobial activity of ozone [4], I explained the therapeutic possibility of ozone to him. Subsequently, he offered to perform the ozone method by himself, and had carried out the treatment by washing the inside of the oral cavity with ozone a couple of minutes every day at the company. Following this oral washing with ozone for about 3 months, his skin lesions nearly completely resolved. It is notable that even after stopping the ozone treatment at about 6 months, there has been no recurrence of this disease for more than 8 years.

These accumulated findings, including the author's experiment and related literature [2,3], may support the fact that oral bacteria can be a potential cause of PPP. Ozone $\left(\mathrm{O}_{3}\right)$ [4] exhibits a strong sterilizing activity which can kill bacteria, fungi, and viruses mechanically. Recently, the ozone nano-bubble (ONB) water (NAGA Co.,Ltd. Japan) [4], which is treated with nano-sized ozone gas, has been made available, and reveals strong antiseptic effects by which periodontal pathogens are eradicated within approximately 30 s of exposure. Clinical trials in dentistry with ONB water [5] as an adjunctive antiseptic for treating periodontitis have begun. Therefore, ozone shows promising potential as a treatment for PPP. I expect that the cause of this disease could be periodontopathic bacteria and that a reliable and safer treatment method is established that includes ozone.

\section{Acknowledgements}

Ozone treatment in this case was performed at the patient's own discretion.

\section{Consent}

The examination of the patient was conducted according to the Declaration of Helsinki principles.

\footnotetext{
How to cite this article: Horiuchi Y. Palmoplantar pustulosis: Oral bacteria as a causative factor and ozone as an effective therapeutic means?. Our Dermatol Online. 2019;10(4):398-399.

Submission: $10.04 .2019 ; \quad$ Acceptance: 18.06 .2019

DOI:10.7241/ourd.20194.25
} 
www.odermatol.com

\section{REFERENCES}

1. Brunasso G, Massone C. Palmoplantar pustulosis: Epidemiology, clinical features, and diagnosis. UpToDate 2015 [open access]

2. Kikuchi N, YamamotoT. Dental infection as a triggering factor for palmoplantar pustulosis. Acta Derm Venereol. 2013;93:721-2.

3. Murai O, Suwabe K, Ohkawa Y, Sasaki D, Yaegashi T. Palmoplantar pustulosis and periodontal therapy. Nihon Shishubyo Gakkai Kaishi (J Jap Society of Periodontol). 2018; 60:131-8.

4. Hayakumo S, Arakawa S, Takahashi M, Kondo K, Mano Y, Izumi Y. Effects of ozone nano-bubble water on periodontopathic bacteria and oral cells- in vitro studies. Sci Tech Adv Mater. 2014;15:055003.
5. Hayakumo S, Arakawa S, Mano Y, Izumi Y. Clinical and microbiological effects of ozone nano-bubble water irrigation as an adjunct to mechanical subgingival debridement in periodontitis patients in a randomized controlled trial. Clin Oral Investig. 2013; 17:379-88.

Copyright by Yasuhiro Horiuchi. This is an open-access article distributed under the terms of the Creative Commons Attribution License, which permits unrestricted use, distribution, and reproduction in any medium, provided the original author and source are credited.

Source of Support: Nil, Conflict of Interest: None declared. 